\title{
UPAYA PEMBINAAN KEPALA SEKOLAH DALAM MENINGKATKAN PROFESIONALITAS GURU DI MADRASAH IBTIDAIYAH NEGERI 2 PIDIE
}

\author{
Nurhayati \\ Kementerian Agama Kabupaten Pidie
}

\begin{abstract}
ABSTRAK
Penelitian ini bertujuan untuk mengetahui pembinaan yang dilakukan kepala sekolah dalam meningkatkan profesionalitas guru di Madrasah Ibtidaiyah Negeri 2 Pidie, yang meliputi empat aspek yakni: aspek kelompok kerja guru, aspek supervisi, aspek seminar atau workshop, dan aspek pendidikan dan pelatihan. Penelitian ini menggunakan pendekatan deskriptif kualitatif Subjek dalam penelitian adalah guru Madrasah Ibtidaiyah Negeri 2 Pidie dengan responden guru di Madrasah Ibtidaiyah Negeri 2 Pidie. Teknik sampling dalam penelitian ini menggunakan proportionate random sampling, dengan jumlah sampel sebanyak 10 guru. Pengumpulan data menggunakan metode wawancara tidak terstruktur. Uji validitas menggunakan observasi dari Person, sedangkan uji reliabilitas menggunakan bimbingan teknis. Analisis data mengunakan analisis deskriptif dengan persentase. Hasil penelitian menunjukkan bahwa pembinaan profesionalitas guru oleh kepala sekolah di Madrasah Ibtidaiyah Negeri 2 Pidie masuk dalam kategori baik dengan capaian persentase $85 \%$. Hal ini dikarenakan kepala sekolah kepala sekolah rutin dalam melaksanakan pembinaan guru khususnya pembinaan melalui supervisi, serta memfasilitasi guru untuk berpartisipasi aktif dalam KKG, seminar atau workshop, dan pendidikan dan pelatihan.
\end{abstract}

Kata kunci: Pembinaan Profesionalitas Guru, Profesionalitas, Kepala Sekolah

\begin{abstract}
This study aims to determine the guidance carried out by the principal in improving the professionalism of teachers at Madrasah Ibtidaiyah Negeri 2 Pidie, which includes four aspects, namely: aspects of teacher work groups, aspects of supervision, aspects of seminars or workshops, and aspects of education and training. This study used a qualitative descriptive approach. The subjects in the study were teachers at Madrasah Ibtidaiyah Negeri 2 Pidie and the respondents were teachers at Madrasah Ibtidaiyah Negeri 2 Pidie. The sampling technique in this study was using proportionate random sampling, with a total sample of 10 teachers. Data collection using unstructured interview method. The validity test uses observation from Person, while the reliability test uses technical guidance. Data analysis used descriptive analysis with percentages. The results showed that the professional development of teachers by the principal at Madrasah Ibtidaiyah Negeri 2 Pidie was in the good category with a percentage of $85 \%$. This is because the principal is routine in carrying out teacher coaching, especially guidance through supervision, as well as facilitating teachers to actively participate in $\mathrm{KKG}$, seminars or workshops, and education and training.
\end{abstract}

Key words: Teacher Professional Development, Professionalism, Principal 


\section{PENDAHULUAN}

Pendidikan yang bermutu merupakan harapan dari setiap warga negara termasuk di Indonesia. Pendidikan yang bermutu akan menghasilkan sumber daya yang bermutu pula, diatur dalam Undang-undang RI Nomor 20 Tahun 2003 tentang Sistem Pendidikan Nasional, Bab II Pasal 3, menyatakan bahwa,"Pendidikan nasional berfungsi mengembangkan kemampuan dan membentuk watak serta peradaban bangsa yang bermartabat dalam rangka mencerdaskan kehidupan bangsa". Hal ini menyiratkan sikap profesionalisme dalam dunia pendidikan menjadi penting, tidak hanya sekadar nilai formalitas tetapi harus fungsional dan menjadi prinsip dasar yang melandasi aksi operasionalnya. Ditinjau dari faktor manajemen, khususnya manajemen pendidikan menurut Sahertian, ada tiga faktor utama yang menyebabkan rendahnya mutu pendidikan, yaitu: (1) instrumental sistem pendidikan, (2) sistem manajemen pendidikan, (3) substansi manajemen pendidikan, antara lain kualitas tenaga pendidik yang kurang profesional, kualitas personil yang kurang memadai yaitu dalam arti penempatan orang yang tepat sesuai dengan kompetensi yang diperlukan untuk kinerja yang efektif dan efisien belum sesuai, dan tingkat kesejahteraan guru yang rendah. Rendahnya kualitas sumber daya manusia khususnya tenaga pendidik/guru merupakan salah satu masalah utama dalam dunia pendidikan, tenaga pendidik/guru yang berkualitas merupakan salah satu komponen yang sangat penting dalam menentukan keberhasilan dalam mencapai sebuah tujuan pendidikan.

Tenaga pendidik/guru yang berkualitas harus ada di dalam sebuah lembaga salah satunya adalah sekolah dasar/madrasah ibtidaaiyah, karena sekolah dasar/ madrasah ibtidaaiyah merupakan sebuah sistem pendidikan yang memiliki tujuan meningkatkan mutu pendidikan, oleh karena itu dapat ditempuh dengan beberapa strategi antara lain: peningkatan kesejahteraan bagi pendidik, mengadakan berbagai jenis kegiatan pelatihan untuk peningkatan kualitas pendidik, dan pembinaan yang dilakukan oleh kepala sekolah bagi pendidik. Hal tersebut dilakukan dengan tujuan untuk meningkatkan kualitas pendidik atau guru terutama dalam mengembangkan proses pembelajaran. Hal ini berdasarkan keyakinan bahwa mutu pendidikan pada akhirnya sangat ditentukan oleh guru/tenaga pendidik dalam proses pembelajaran. Menurut Kunandar, guru merupakan pendidik profesional dengan tugas utama mendidik, mengajar, membimbing, mengarahkan, melatih, menilai, dan mengevaluasi peserta didik pada pendidikan anak usia dini jalur pendidikan formal, pendidikan dasar, dan pendidikan menengah. Guru sebagai ujung tombak proses pendidikan memiliki banyak dimensi peran yang harus diembannya dalam konteks pencapaian tujuan pendidikan. Sebagai ujung tombak, kualitas guru akan menentukan kualitas mutu layanan dan lulusan yang dihasilkan. Sebagaimana dalam Undang undang No. 14 Tahun 2005 tentang Guru dan Dosen (pasal 1) dinyatakan bahwa," guru adalah pendidik profesional dengan tugas utama mendidik, mengajar, membimbing, mengarahkan, melatih, menilai, dan mengevaluasi peserta didik pada 2 jalur pendidikan formal, pada jenjang pendidikan dasar dan pendidikan menengah". Guru yang profesional harus bisa menerapkan cara mengajar yang baik dan dapat berpengaruh terhadap hasil siswa itu sendiri. Hal tersebut tidak jauh dari peran seorang kepala sekolah. Kepala sekolah bertugas melakukan supervisi, mengkoordinir, membimbing, memotivasi, memimpin dan mengoreksi kepada guru untuk dapat mengetahui sejauh mana kompetensi guru tersebut terutama dalam mengajar dan menyampaikan materi kepada siswa.

Profesionalitas guru selain dilihat dari sertifikasi guru, saat ini dapat dilihat dari 
bagaimana guru menyesuaikan dengan perubahan kurikulum yang sering 3 berubahubah, seperti kurikulum sekarang ini yang telah berubah menjadi kurikulum 2013. Kurikulum 2013 untuk SD/MI menggunakan pendekatan pembelajaran tematik integratif dari kelas I sampai dengan kelas VI. Pembelajaran tematik integratif merupakan pendekatan pembelajaran yang mengintegrasikan berbagai kompetensi dan berbagai mata pelajaran ke dalam berbagai tema. Dalam pembelajaran tematik ini para guru memiliki tugas yang cukup berat untuk dapat menerapkan sistem atau metode mengajar terbaru yang lebih dikembangkan lagi sehingga pembinaan dalam hal ini diperlukan terutama terhadap ketidaksiapan guru dengan adanya kurikulum terbaru agar dapat menyesuaikannya. Guru madrasah sendiri dituntut untuk meningkatkan kompetensi menguasai seluruh mata pelajaran yang diajarkan dan menghubungkan setiap mata pelajaran dengan kehidupan sehari-hari sesuai dengan harapan masa depan pendidikan. Guru yang profesional tersebut menjadi dambaan para siswa, oleh karena itu kompetensi guru hendaknya juga harus ditingkatkan untuk menjamin pendidikan lebih bermutu karena akan berakibat pada tinggi rendahnya mutu pendidikan di lembaga pendidikan tersebut. Dengan memiliki kemampuan mengajar yang bervariasi, guru madrasah diharapkan mampu menerapkan keterampilan mengajarnya yang dapat membuat peserta didik tertarik akan belajar, situasi belajar yang menyenangkan, sehingga para siswa tidak merasa jenuh ataupun bosan dan lebih termotivasi dalam proses belajar mengajar.

Dari hasil wawancara awal dengan beberapa kepala madrasah di Madrasah ibtidaiyah Negeri 2 Pidie, masih terdapat beberapa kendala diantaranya, pertama guru yang sudah lulus sertifikasi dan mendapatkan gelar guru profesional belum meningkatkan kinerjanya dan belum bisa merealisasikan gelarnya tersebut, kedua guru belum mengoptimalkan IT untuk mendukung kegiatan belajar dan masih menggunakan metode ceramah dan mencatat, dan ketiga kurangnya guru dalam melakukan perbaikan pembelajaran melalui penelitian tindakan kelas dan perangkat pembelajaran seperti RPP, bahan ajar, media pembelajaran, dan instrumen evaluasi yang belum disusun dengan baik. Berdasarkan kenyataan tersebut, maka terdapat beberapa cara yang dapat dilakukan untuk meningkatkan profesionalitas guru diantaranya dengan adanya pembinaan terhadap guru yang dilaksanakan secara teratur oleh kepala madrasah. Pembinaan yang dilakukan tersebut adalah pembinaan sebagai upaya kegiatan usaha terus menerus untuk memperbaiki, menyempurnakan, dan mengembangkan kemampuan, untuk mencapai tujuan keberhasilan pendidikan. Dengan pembinaan yang dilakukan secara bertahap dan terus menerus, maka guru-guru tersebut akan meningkatkan kemampuan profesionalnya sehingga mutu situasi belajar mengajar dapat ditingkatkan. Usaha pembinaan profesional yang dilakukan kepala madrasah terhadap guru diharapkan dapat menambah kesadaran guru yaitu dengan inisiatif dirinya sendiri tanpa harus menunggu atau mendapat perintah dan ajakan dari orang lain dalam berusaha untuk meningkatkan kompetensinya. Hal ini menandakan bahwa guru tersebut menginginkan menjadi berkembang untuk menjadi guru yang lebih baik lagi dalam melaksanakan tugas sebagai pendidik. Pembinaan yang dilakukan untuk meningkatkan profesional tersebut antara lain melalui pendidikan dan pelatihan seminar, studi lanjut, buku, dan IPTEK.

Pembinaan profesional guru sendiri memiliki beberapa landasan hukum diantaranya adalah Undang-undang Republik Indonesia No. 20 Tahun 2003 Pasal 39 tentang Sistem Pendidikan Nasional, Undang-undang No. 14 Tahun 2005 Pasal 34 tentang Guru dan Dosen, dan Peraturan Pemerintah Republik Indonesia No. 19 tentang Standar Nasional Pendidikan. 
Mengacu pada peraturan perundangan tersebut, 6 pelaksanaan pembinaan profesional guru meliputi kompetensi pedagogik, kompetensi kepribadian, kompetensi sosial dan kompetensi profesional. Namun, dalam penelitian ini hanya membahas pembinaan guru pada kompetensi pedagogik dan kompetensi profesional saja. Pembinaan tersebut bertujuan untuk meningkatkan kualitas proses dan hasil belajar sehingga tujuan pendidikan yang direncanakan dapat tercapai dan mendapatkan hasil yang bermutu. Dari data observasi awal melalui wawancara dengan beberapa guru Madrasah Ibtidaiyah Negeri 2 Pidie, bahwa pembinaan oleh kepala madrasah terhadap guru sudah dilaksanakan namun belum maksimal, misalnya dalam hal pemberian penjelasan tentang bagaimana cara mengajar dan menyampaikan materi belajar yang baik, pemberian solusi terhadap beberapa masalah yang dihadapi oleh sebagian guru, membimbing guru dalam penggunaan IT sebagai pendukung kegiatan belajar mengajar karena kepala madrasah menganggap semua guru sudah dapat menggunakan IT dengan cukup baik dan membimbing guru dalam persiapan pelaksanaan kurikulum 2013. Madrasah Ibtidaiyah Negeri 2 Pidie dipilih sebagai objek penelitian dikarenakan sangat tepat dilakukan. Oleh karena itu, pembinaan disini sangat berpengaruh terhadap 7 keprofesionalan guru-guru di sekolah tersebut.

Berdasarkan hasil observasi awal yang dilakukan penulis di Madrasah Ibtidaiyah Negeri 2 Pidie melalui Dinas Pendidikan, menemukan beberapa permasalahan diantaranya: (1) meskipun guru telah mengikuti pelatihan, dalam mengajar guru cenderung masih menggunakan cara lama atau konvensional dan terkesan monoton, seperti siswa cenderung hanya mendengarkan penjelasan dari guru dan harus dihafalkan sehingga siswa pasif dalam pembelajaran; (2) masih banyak guru yang sudah mendapat sertifikasi menjadi kurang terpacu dan termotivasi untuk memberdayakan diri mengembangkan profesionalitas diri dan memutakhirkan pengetahuan mereka secara terus menerus dan berkelanjutan meskipun telah mengikuti program pendidikan. Hal tersebut yang dialami Madrasah Ibtidaiyah Negeri 2

Pidie, sebab kemampuan guru harus terus dikembangkan dan ditingkatkan khususnya untuk guruguru yang belum bersertifikasi dan honorer, karena profesional guru tidak berhenti begitu saja dengan status sertifikasi yang telah didapat. Kerjasama yang baik antara kepala madrasah, guru dan siswa juga sangat perlu untuk dapat mewujudkan kegiatan belajar mengajar yang baik dan kondusif di sekolah tersebut. Disini kepala madrasah berperan sangat penting dalam hal pembinaan terhadap guru-guru tersebut agar guru menjadi terpacu dan menjadi lebih baik lagi. Oleh karena itu, penulis tertarik dan penting untuk melakukan penelitian tentang Upaya Pembinaan Kepala madrasah dalam Meningkatkan Profesionalitas Guru di Madrasah Ibtidaiyah Negeri 2 Pidie, untuk mengetahui secara mendalam tentang upaya pembinaan yang dilakukan kepala sekolah dalam meningkatkan profesionalitas guru.

Berdasarkan latar belakang, identifikasi dan batasan masalah di atas, maka peneliti merumuskan masalah yang akan diteliti yakni "bagaimana pembinaan kepala madrasah dalam meningkatkan profesionalitas guru di Madrasah Ibtidaiyah Negeri 2 Pidie?" Berdasarkan rumusan masalah di atas, maka penelitian ini bertujuan untuk mengetahui bagaimana pembinaan yang dilakukan kepala madrasah dalam meningkatkan profesionalitas guru di Madrasah Ibtidaiyah Negeri 2 Pidie.

\section{PEMBAHASAN Kajian Teori}

Untuk mengembangkan pengetahuan, bakat, serta keterampilan guru, langkah atau upaya yang perlu dilakukan suatu lembaga 
pendidikan adalah melalui pembinaan. Pembinaan tersebut perlu dilakukan secara teratur dan kontinyu untuk usaha-usaha perbaikan dan pengembangan. Menurut Depdikbud, menyebutkan bahwa, "pembinaan adalah usaha memberi bantuan pada guru untuk memperluas pengetahuan, meningkatkan keterampilan mengajar dan menumbuhkan sikap profesional, sehingga guru menjadi lebih ahli mengelola kegiatan belajar mengajar dalam membelajarkan anak didik". Sedangkan menurut Kamus Besar Bahasa Indonesia, " pembinaan adalah proses, cara, perbuatan membina, pembaharuan, penyempurnaan, dan usaha, tindakan dan penyempurnaan, dan usaha, tindakan dan kegiatan yang dilakukan secara efektif dan efisien untuk memperoleh hasil yang lebih baik." Berdasarkan pendapat tersebut maka dapat disimpulkan bahwa pembinaan adalah kegiatan dengan tujuan untuk memperluas pengetahuan, meningkatkan kemampuan dan keterampilan mengajar, serta menumbuhkan sikap profesionalyang dilakukan secara efektif dan efisien untuk memperoleh hasil yang lebih baik.

Berkaitan dengan tujuan pembinaan yang dilakukan oleh kepala sekolah yaitu untuk mengembangkan situasi belajar mengajar yang lebih baik dan berkualitas khususnya bagi guru, maka dalam pembinaan sendiri diperlukan beberapa teknikteknik pembinaan agar pembina dapat melaksanakan tugas secara spesifik. Ada sejumlah teknik pembinaan guru yang dikemukakan oleh beberapa ahli. Dari sejumlah teknik yang dikemukakan oleh para ahli tersebut, dapat dibedakan menjadi dua golongan yaitu teknik perorangan (individual techniques) maupun secara kelompok (group techniques) dan teknik yang bersifat langsung yaitu bertatap muka ataupun teknik yang bersifat tidak langsung yaitu melalui media komunikasi (visual, audial, audiovisual).

Sekolah merupakan organisasi sosial yang menyediakan layanan pembelajaran bagi masyarakat. Sedangkan Wahjosumidjo mengemukakan bahwa,"sekolah merupakan organisasi yang kompleks dan unik, organisasi yang kompleks karena di dalam sekolah terdapat sumber daya yang saling terkait, sedangkan sebagai organisasi yang unik karena sekolah menjadi tempat proses belajar mengajar dan pembudaya kehidupan umat manusia". Guna mendayagunakan sumberdaya tersebut agar dapat dimanfaatkan seoptimal mungkin untuk dapat mencapai tujuan sekolah yang telah ditetapkan, diperlukan seorang pemimpin sekolah yang mampu beperan sesuai dengan tugas, wewenang dan tanggung jawabnya. Pendapat tersebut dipertegas oleh Sudarwan Danim yang mengemukakan bahwa keberhasilan peningkatan mutu sekolah sangat ditentukan oleh kemampuan kepala sekolah dalam memimpin dan memberdayakan staf pengajar dan anggota komunitasnya secara keseluruhan. Maka dari itu peran kepala sekolah sangatlah penting dalam meningkatkan kemajuan sekolah. Suharsimi Arikunto mendefinisikan kepala sekolah sebagai penilik, karena kepala sekolah sangat paham dengan kehidupan sekolah sehari-hari. Seorang kepala sekolah menduduki jabatannya karena ditetapkan dan diangkat oleh atasan (Kepala Kantor Departemen Pendidikan dan Kebudayaan atau Yayasan), tetapi untuk menjalankan tugasnya dengan baik dan lancar, seorang kepala sekolah perlu diterima oleh guru-guru yang dipimpinnya. Sedangkan menurut Wahjosumidjo, kepala sekolah adalah seorang tenaga profesional guru yang diberi tugas untuk memimpin suatu sekolah dimana sekolah tersebut menjadi tempat proses belajar mengajar dan terjadi interaksi antara guru yang memberi pelajaran dengan murid yang menerima pelajaran. Kata "memimpin" dari rumusan tersebut mengandung makna luas, yaitu kemampuan untuk menggerakan segala sumber yang ada pada suatu sekolah sehingga dapat didayagunakan secara maksimal untuk mencapai tujuan yang telah ditetapkan. Dalam praktik lembaga, kata 
Jurnal Sosial Humaniora Sigli (JSH)

p ISSN : 2615-3688

e ISSN : 2716-0270

http://journal.unigha.ac.id/index.php/JSH

"memimpin" mengandung konotasi

"menggerakkan, mengarahkan, membimbing, melindungi, membina, memberikan teladan, memberikan dorongan, memberikan bantuan, dan lain-lain". Kepala sekolah merupakan manager di lembaga yang dipimpinnya. Tugas dan tanggung jawab kepala sekolah sangat kompleks sehingga perlu ketentuan kualitas standar minimal yang harus dipenuhi serta kelayakan pendidikannya harus relevan dengan tugas dan tanggung jawab yang diembannya. Kepala sekolah sebagai pemimpin institusi pendidikan mempunyai fungsi dan peranan yang beragam menurut tingkat dan jenjang pendidikannya.

Implementasi tugas pokok dan fungsi kepala sekolah tidak cukup mengandalkan aksi- aksi praktis dan fragmatis, melainkan berbasis pada pengetahuan di bidang manajemen dan kepemimpinan yang cerdas. Hakikat pengetahuan adalah segenap apa yang kepala sekolah ketahui tentang suatu objek tertentu. Konntz menyatakan bahwa pengetahuan kekepalasekolahan yang harus dimiliki oleh kepala sekolah dan paling relevan dengan tugas pokok dan fungsinya adalah pengetahuan manajemen yang dapat diaplikasikan secara efektif dalam praktik. Hal tersebut diperkuat oleh Sudarwan Danim dan Suparno yang mengungkapkan bahwa pelaksanaan manajemen sekolah, baik konvensional maupun yang menggunakan berbasis sekolah, akan dapat berhasil dan berjalan dengan baik jika didukung oleh kepemimpinan kepala sekolah yang secara fungsional mampu berperan sesuai dengan tugas, wewenang dan tanggung jawabnya. Dengan kata lain kepala sekolah dituntut mampu mensinergikan seluruh komponen dan potensi sekolah dan lingkungan sekitarnya supaya tercipta kerja sama untuk memajukan sekolah. Kepala sekolah harus mampu menjadi manajer yang efisien dan pemimpin yang efektif. Dia harus memiliki kemampuan manajemen dan dapat menampilkan sikap dan sifat sebagai kepala sekolah.
Teknik-teknik pembinaan guru dalam buku Pedoman Pembinaan Guru yang dikeluarkan oleh Depdikbud meliputi: kunjungan kelas, pertemuan pribadi, rapat dewan guru, kunjungan antar kelas, kunjungan sekolah, kunjungan antar sekolah, pertemuan dalam kelompok kerja, penerbitan profesional dan penataran. Adapun beberapa program yang dapat dilakukan oleh kepala sekolah dalam meningkatkan kinerja guru :

1) Kunjungan Kelas

2) Pertemuan Pribadi

3) Rapat Dewan Guru

4) Kunjungan antar Kelas

5) Kunjungan antar Sekolah

6) Pertemuan dalam Kelompok Kerja

7) Penerbitan Bulletin Profesional dan Penataran

Pembinaan profesional guru sasarannya adalah semua guru yang dipimpinnya, dan tujuan pembinaan profesional guru adalah untuk meningkatkan kualitas sumber daya tenaga kependidikan yang tersedia sehingga dapat meningkatkan kualitas proses pendidikan itu sendiri, dan pada gilirannya kualitas prestasi belajar dan output semakin bermutu. Selanjutnya dalam Depdiknas, tujuan umum dari sistem pembinaan profesional adalah untuk meningkatkan mutu pendidikan melalui peningkatan pelayanan profesional kepada guru.

Menurut UU No. 14 Tahun 2005 tentang Guru dan Dosen Pasal 1 Ayat 10, disebutkan bahwa kompetensi adalah seperangkat pengetahuan, keterampilan, dan perilaku yang harus dimiliki, dihayati, dan dikuasai oleh guru atau dosen dalam melaksanakan tugas keprofesionalan. Dalam Kamus Umum Bahasa Indonesia kompetensi berarti (kewenangan) kekuasaan untuk menentukan atau memutuskan sesuatu hal. Menurut Broke and Stone seperti yang dikutip oleh Moh. Uzer Usman, "competency is descriptive of qualitative nature of teacher behavior appears it be entirely meaningful". Kompetensi merupakan gambaran hakikat kualitatif dari perilaku guru yang tampak 
sangat berarti. Sedangkan menurut Charles E. Johnson, competency as a rational performance which satisfactorily meets the objective for a desired condition".

Dengan peraturan yang telah dikeluarkan oleh UU No. 14 Tahun 2005 tentang Guru dan Dosen, bahwa sertifikat pendidik diberikan kepada guru yang telah memenuhi persyaratan kualifikasi akademik dan kompetensi sebagai agen pembelajaran, kondisi tersebut berdampak pada guru yang belum bersertifikat untuk segera melengkapi berbagai persyaratan yang ditentukan. Sedangkan bagi yang telah menerima sertifikat pendidik pada kenyataannya memunculkan dampak positif dan dampak negatif. Dampak positif dapat dilihat dari tanggung jawab guru untuk meningkatkan keprofesionalan mereka sesuai bidang keahliannya sehingga perilakunya dapat dilihat dari meningkatnya aktifitas pembelajaran baik untuk mereka sendiri maupun untuk peserta didik. Dampak negatif terlihat pada penurunan aktifitas pembelajaran yang seharusnya dilaksanakan. Pencapaian dalam kepemilikan sertifikat beserta tunjangan keprofesionalan yang diberikan pemerintah dianggap sebagai puncak pencapaian kinerja sehingga tanpa peningkatan apapun mereka sudah mendapatkannya. Kondisi ini menyebabkan tidak ada perubahan, bahkan kemungkinan terjadi penurunan kinerja bila dibandingkan antara sebelum menerima sertifikat dan sesudah menerima sertifikat. Agar tidak terjadi dampak negatif tersebut, maka perlu dilaksanakan penilaian berkelanjutan dan pengembangan terhadap guru sebagai wujud nyata penjaminan mutu guru profesional.

Menurut UU Nomor 14 tahun 2005 tentang Guru dan Dosen, profesional adalah pekerjaan atau kegiatan yang dilakukan oleh seseorang dan menjadi sumber penghasilan atau kegiatan yang dilakukan oleh seseorang dan menjadi sumber penghasilan kehidupan yang memerlukan keahlian, kemahiran, atau kecakapan yang memenuhi standar mutu atau norma tertentu serta memerlukan pendidikan profesi. Pendapat lain dikemukakan oleh Moh. Uzer Usman, disebutkan bahwa istilah profesional berarti a vocation an which professional knowledge of some department a learning science is used in its applications to the of other or in the practice of an art found it. Ungkapan tersebut mengandung makna bahwa suatu pekerjaan yang bersifat profesional memerlukan beberapa bidang ilmu yang secara sengaja harus dipelajari dan kemudian di aplikasikan bagi kepentingan umum, atas dasar tersebut ternyata profesional berbeda dengan pekerjaan lainnya, karena suatu profesi memerlukan kemampuan dan keahlian khusus dalam melaksanakan profesinya.

Upaya peningkatan profesionalitas guru secara garis besar merupakan tuntutan untuk mengikuti arus perkembangan ilmu pengetahuan dan teknologi yang berjalan cepat. Agar tugas, peranan, dan tanggungjawab guru selalu up to date, maka guru harus selalu mengembangkan kompetensinya dengan berbagai kegiatan yang mendukung dalam tugas mengajarnya. Peningkatan kompetensi guru hendaknya dilakukan melalui pembinaan dan pengembangan profesi dan karir. Pada pasal 32 ayat (1) Undang-undang Nomor 14 tahun 2005 tentang Guru dan Dosen dinyatakan bahwa pembinaan dan pengembangan profesi meliputi kompetensi pedagogik, kompetensi kepribadian, kompetensi sosial, dan kompetensi profesional. Dengan pembinaan dan pengembangan terhadap kompetensi dasar yang harus dimiliki guru, diharapkan mampu menambah kemampuan guru dalam menunjang terwujudnya proses pembelajaran yang berkualitas. Peningkatan profesi adalah kegiatan guru dalam rangka pengamalan ilmu dan pengetahuan, teknologi, dan keterampilan untuk meningkatkan mutu, baik proses belajar mengajar, dan profesionalisme tenaga 
kependidikan lainnya maupun dalam rangka menghasilkan sesuatu yang bermanfaat bagi pendidikan dan kebudayaan.

Moral kerja merupakan suatu sikap dan tingkah laku yang berbentuk semangat seseorang dalam bekerja. Semangat kerja seseorang ini sangat mempengaruhi produktivitas seseorang. Jadi jika seseorang memiliki moral kerja yang tinggi, maka kemungkinan besar akan menghasilkan sesuatu yang lebih banyak dan lebih baik dalam kinerjanya. Lucio dan Neil mengemukakan konsep moral kerja seperti yang dikutip oleh Ibrahim Bafadal "Morale was regarded as the attitude and behavior which denoted a willingness to be involved in school and it's work". Dari konsep tersebut dapat dilihat bahwa moral sebagai suatu sikap dan tingkah laku yang merupakan perwujudan suatu kemauan yang dibawa serta ke sekolah dan kerjanya. Sehingga moral kerja seseorang merupakan perwujudan kemauan seseorang melalui sikap dan tingkah laku. Moral kerja guru perlu dibina agar semangat kerja guru senantiasa tinggi sehingga kinerja guru semakin baik. Pembinaan ini menitikberatkan pada guru yang memiliki moral kerja yang tinggi yang nantinya akan mempertinggi produktifitas kerja. Artinya seorang guru memiliki moral kerja yang tinggi akan produktif, yaitu akan menghasilkan sesuatu yang lebih baik dari hasil kerjanya dalam rangka mencapai tujuan pendidikan.

Tuntutan perkembangan ilmu pengetahuan dan teknologi yang semakin cepat membuat guru selalu berupaya untuk meningkatkan kompetensi profesionalnya. Semua guru baik yang telah sertifikasi maupun yang belum sertifikasi wajib untuk selalu meningkatkan kemampuan profesionalnya. Hal ini dikarenakan tugas, peran, dan tanggung jawab seorang guru sebagai agen pembelajaran di sekolah. Tugas, peranan, dan tanggung jawab guru yang harus sesuai dengan tuntutan perkembangan yang ada, maka guru harus selalu mengembangkan kompetensinya dengan berbagai kegiatan yang mendukung dalam tugas mengajarnya. Oleh sebab itu, perlu adanya pembinaan yang harus dilakukan oleh kepala sekolah yang bersangkutan. Dari penjelasan sebelumnya juga telah disebutkan beberapa bentuk-bentuk pembinaan profesional guru untuk meningkatkan profesionalitas guru. Dari bentuk-bentuk pembinaan tersebut kepala sekolah berkewajiban dan memiliki wewenang untuk melakukan pembinaan-pembinaan terhadap guru di sekolah yang dipimpinnya tersebut. Untuk mencapai keberhasilan dan pembinaan, maka kepala sekolah harus memperbaiki dan meningkatkan pembinaan yang dilakukannya. Menurut Suharsimi Arikunto yang dikutip oleh Sam M Chan dan Tuti T. Sam, mengemukakan bahwa kunci keberhasilan kepala sekolah selaku supervisor di sekolahnya adalah mengusahakan peningkatan kemampuan para guru dan stafnya untuk secara bersamasama mengembangkan situasi belajar mengajar yang kondusif. Jadi, kepala sekolah sangat dituntut mempunyai kemampuan berkomunikasi yang baik, sehingga peranannya tersebut tidak lagi menjadi sesuatu yang mengkhawatirkan bagi guru.

Penelitian ini ditujukan untuk mengetahui pembinaan yang diberikan kepala sekolah terhadap profesional mengajar guru. Penelitian mengenai pembinaan profesional mengajar guru oleh kepala sekolah di belum pernah dilakukan sebelumnya. Adapun penelitian yang relevan atau mempunyai kesamaan dengan yang dilakukan oleh peneliti ini adalah sebagai berikut: Penelitian yang dilakukan oleh Bambang Purwanto, dalam tesisnya yang berjudul "Pelaksanaan Pembinaan oleh Kepala Sekolah dalam Meningkatkan Kinerja Guru S ekolah Dasar di Madrasah Ibtidaiyah Negeri 2 Pidie", yang kesimpulannya membahas bahwa: 
Pelaksanaan pembinaan oleh kepala sekolah dalam meningkatkan kinerja guru di Madrasah Ibtidaiyah Negeri 2 Pidie secara umum tergolong cukup.

Rendahnya kualitas sumber daya manusia khususnya tenaga pendidik/guru merupakan salah satu masalah utama dalam dunia pendidikan. Tenaga pendidik/guru merupakan salah satu komponen yang sangat penting dalam menentukan keberhasilan dalam mencapai sebuah tujuan pendidikan, oleh sebab itu guru harus berkualitas dan sesuai dengan standar profesional guru yang ada. Guru dituntut untuk meningkatkan kualitas dan kompetensinya sehingga guru harus dapat menguasai kompetensi guru yang telah ada. Oleh sebab itu, perlu adanya pembinaan yang dilakukan agar guru lebih baik dalam melaksanakan profesinya dalam mengajar di sekolah. Tujuan pembinaan profesionalitas guru adalah untuk meningkatkan kualitas sumber daya tenaga kependidikan yang tersedia sehingga dapat meningkatkan kualitas proses pendidikan itu sendiri, dan pada gilirannya kualitas prestasi belajar dan output semakin bermutu.

\section{Metode Penelitian}

Pendekatan penelitian yang digunakan dalam penelitian ini adalah pendekatan kuantitatif, karena data yang akan diperoleh berupa angka-angka dan pengolahannya menggunakan metode statistik. Hal ini sesuai dengan pendapat Sugiyono, bahwa penelitian kuantitatif merupakan pendekatan penelitian dengan data penelitiannya berupa angkaangka, dan analisisnya menggunakan statistik.

Jenis penelitian yang digunakan dalam penelitian ini adalah penelitian deskriptif. Bersifat deskriptif karena penelitian ini bertujuan untuk melihat dan mendeskripsikan mengenai upaya yang dilakukan oleh kepala sekolah dalam membina guru yang meliputi pembinaan pada KKG, Supervisi, Seminar, dan Pendidikan dan Pelatihan di Madrasah, Kabupaten Pidie. Hal tersebut sesuai dengan pendapat Suharsimi Arikunto, yang menyatakan bahwa penelitian deskriptif adalah penelitian yang memberikan informasi hanya mengenai data yang diamati dan tidak bertujuan menguji hipotesis serta hanya menyajikan dan menganalisis data agar bermakna dan komunikatif. Penelitian ini dilakukan di Madrasah Ibtidaiyah Negeri 2 Pidie. Penelitian ini dilakukan dari pembuatan proposal sampai dengan laporan pada bulan Oktober 2019 sampai dengan bulan November 2019.

Pada tahap ini penulis menjelaskan bagaimana tahap perencanaan pelitian tindakan supervisi. Pada tahap ini kegiatan yang direncanakan peneliti adalah sebagai berikut:

1. Mengidentifikasi permasalaham guru

2. Menyusun perencanaan pembuatan tema PTS

3. Penjelasan tentang tata cara dan langkahlangkah proposal pembuatan PTS

4. Melakukan penelitiaan

5. Evaluasi

\begin{tabular}{|l|l|l|l|l|l|l|l|l|l|}
\hline \multirow{2}{*}{\multicolumn{1}{c|}{ Kegiatan }} & \multicolumn{7}{|c|}{ Waktu } & Ket \\
\cline { 2 - 10 } & \multicolumn{7}{|c|}{ Oktober } & \multicolumn{3}{c|}{ November } & \\
\cline { 2 - 10 } & 1 & 2 & 3 & 4 & 1 & 2 & 3 & 4 & \\
\hline Pengajuan Proposal & & & & & & & & & \\
\hline Penyusunan Rancangan & & & & & & & & & \\
\hline Pelaksanaan Siklus I & & & & & & & & & \\
\hline Analisis Hasil Siklus I & & & & & & & & & \\
\hline Pelaksanaan Siklus II & & & & & & & & & \\
\hline Analisis Hasil Siklus II & & & & & & & & & \\
\hline Penulisan Hasil penelitian & & & & & & & & & \\
\hline
\end{tabular}

Adapun teknis penelitian ini adalah :

1. Tahap Pelaksanaan/tindakan

2. Perencanaan (Planning)

3. Observasi

4. Refleksi

5. Siklus II

Populasi dalam penelitian ini adalah semua guru di Madrasah Ibtidaiyah Negeri 2 Pidie. Ada dua macam teknik pengambilan sampel yang dapat digunakan dalam penelitian, menurut Riduwan dan Akdon, yaitu probability sampling dan 
Jurnal Sosial Humaniora Sigli (JSH)

p ISSN : 2615-3688

e ISSN : 2716-0270

http://journal.unigha.ac.id/index.php/JSH

nonprobability sampling. Sugiyono, menjelaskan bahwa teknik probability sampling meliputi: simple random, proportionate stratified random, disproportionate stratified random, dan cluster (area) random. Teknik nonprobability sampling meliputi: sampling sistematis, sampling kuota, sampling aksidental, purposive sampling, sampling jenuh, dan snowball sampling. Menurut Suharsimi Arikunto penelitian sampel baru boleh dilaksanakan apabila keadaaan subjek di dalam populasi benar-benar homogen. Apabila subjek populasi tidak homogen, maka kesimpulannya tidak boleh diberlakukan bagi seluruh populasi (hasilnya tidak boleh digeneralisasikan). Penelitian ini merupakan penelitian sampel sehingga cara pengambilan sampel penelitian ini dengan cara proportionate random sampling. Teknik sampling ini merupakan teknik pengambilan sampel yang dilakukan dimana setiap anggota populasi memiliki peluang yang sama untuk dipilih sebagai anggota sampel. Pengambilan sampel ini ditentukan secara seimbang dengan banyaknya sampel dari masing-masing sub populasi. Teknik pengumpulan data yang digunakan dalam penelitian adalah angket atau kuesioner sebagai acuan utama serta didukung dengan wawancara. Wawancara tidak terstruktur yang dilakukan peneliti kepada kepala sekolah mencakup empat aspek pembinaan yang telah disebutkan dalam kisi-kisi yaitu aspek KKG, Supervisi, Seminar atau workshop, dan Pendidikan dan Pelatihan.Pada aspek KKG peneliti melakukan wawancara mengenai pembinaan yang dilakukan oleh kepala sekolah dalam mengembangkan kemampuan profesionalitas guru dalam mengajar dan mengembangkan soal-soal penilaian.

Analisis data yang digunakan dalam penelitian ini yaitu dengan mendeskripsikan data dengan pengukuran persentase. Pengukuran data menggunakan hasil wawancara dan observasi pada 10 responden sebagai sampel. Perhitungan persentase dilakukan untuk mengetahui dan mengukur bagaimana pembinaan profesionalitas guru yang dilakukan oleh kepala sekolah di Madrasah Ibtidaiyah Negeri 2 Pidie.

\section{Hasil Penelitian}

Subjek pada penelitian ini adalah guru Madrasah Ibtidaiyah Negeri 18 Pidie. Subjek yang diteliti sebanyak 10 orang. Objek yang diteliti dalam penelitian ini adalah supervisi akademik oleh pengawas Madrasah Ibtidaiyah Negeri 2 Pidie dengan fokus penelitian intensitas pembinaan penyusunan RPP, teknik mengajar dan menguasai kelas serta tanggung jawab atas tugas pokok masing-masing guru. Dalam penyusunan RPP, guru biasanya bekerja sama dengan rekan guru dalam satu gugus. Mekanisme yang dilakukan adalah dengan membagi tugas antar guru dalam kelas yang sama untuk menyusun RPP tiap pertemuan dan dikumpulkan saat awal semester untuk kemudian di perbanyak sesuai jumlah guru yang membutuhkan. Madrasah Ibtidaiyah Negeri 2 Pidie memiliki jumlah guru sebanyak 67 orang guru yang aktif serta mampu menjalankan semua tugas dan tanggung jawabnya sebagai pendidik. Dapat kita mendeskripsikan mengenai kondisi umum pendidikan dan jumlah guru di Madrasah Ibtidaiyah Negeri 2 Pidie. Guru yang diteliti dari sekolah tersebut diketahui bahwa sebagian memiliki pendidikan akhir sarjana, beberapa diploma dan magister. Peneliti menggali tentang pendidikan terakhir dikarenakan syarat menjadi guru profesional minimal harus memiliki kualifikasi akademik sarjana (S1). Berdasarkan paparan diatas, dapat disimpulkan bahwa sebagian besar guru yang mengajar di Madrasah Ibtidaiyah Negeri 2 Pidie telah memenuhi syarat dalam pencapaian kompetensi profesional dalam hal kualifikasi akademik. Berdasarkan PP Nomor 74 Tahun 2008, kualifikasi akademik guru minimum diperoleh dari pendidikan tinggi program S-1 atau program D-IV pada perguruan tinggi yang menyelenggarakan 
program pendidikan tenaga kependidikan dan/atau program non kependidikan.

Kelompok kerja guru, Madrasah Ibtidaiyah Negeri 2 Pidie yang pelaksanaannya diadakan setiap satu minggu sekali. Sedangkan untuk supervisi, sebagian besar kepala sekolah melakukan supervisi akademik dan supervisi klinis yang dilaksanakan sesuai dengan kebutuhan kepala sekolah masing-masing terhadap guru yang perlu disupervisi. Minimal setiap dua minggu sekali kepala sekolah mengadakan rapat untuk membahas kendala dan permasalahan yang ada di sekolah khususnya pada proses kegiatan belajar mengajar. Selanjutnya untuk seminar atau workshop dan pendidikan dan pelatihan dilaksanakan minimal dua kali dalam setahun. Madrasah Ibtidaiyah Negeri 2 Pidie memiliki jumlah siswa sebanyak 227 siswa. Mengenai jumlah siswa di Madrasah Ibtidaiyah Negeri 2 Pidie. Dapat dilihat bahwa jumlah siswa laki-laki lebih banyak dibandingkan dengan jumlah siswa perempuan, namun hal tersebut tidak berpengaruh ataupun menjadi kendala guru dalam melaksanakan kegiatan belajar mengajar. Dapat dilihat pula bahwa jumlah siswa per kelas sudah cukup merata sehingga rasio antara jumlah guru dan siswa di sebagian besar Madrasah Ibtidaiyah Negeri 2 Pidie sudah baik, karena antara jumlah siswa dengan guru yang mengajar di sekolah tersebut telah sesuai dan tidak kekurangan pengajar.

Kemampuan guru dalam melakukan tugas dan tanggung jawab sangat perlu diperhatikan walaupun ada beberapa guru yang sudah mampu menguasai tehnik-teknik yang dasar dalam menguasai ruang aataupu mengendalikan situasi ketika proses belajar mengajar. Dari hasil suvervisi penulis sebagai pengawas Madrasah Ibtidaiyah Negeri 2 Pidie hanya $38 \%$ guru yang mampu menjalankan tugasnya dengan profesional untuk proses mengajar. Rendahnya profesionalitas guru dalam menjalankan tugas serta tanggung jawab disebabkan kurangnya bimbingan serta pelatihan kusus dan juga pendampingan langsung dari orang yang profesional dalam bidang dan keahliannya. Berikut ini adalah deskripsi Siklus I :

1. Perencanaan (Planning)

2. Refleksi

3. Pelaksanaan

4. Pengamatan

\begin{tabular}{|c|l|c|}
\hline No & Nama & $\begin{array}{c}\text { Skor } \\
\text { Penilaaian }\end{array}$ \\
\hline 1 & Nurjanida, S. Pd. I & 3 \\
\hline 2 & Megawati, S. Pd. I & 3 \\
\hline 3 & Mukhsin, S. Pd. I & 3 \\
\hline 4 & Razali, S. Pd. I & 3 \\
\hline 5 & Murniati, S. Pd. I & 3 \\
\hline 6 & Mawarni, S. Pd. I & 3 \\
\hline 7 & Nurlaili, S. Pd. I & 3 \\
\hline 8 & Azimar, S. Pd. I & 3 \\
\hline 9 & Masriani, S. Pd. I & 3 \\
\hline 10 & Darni, S. Ag & \\
\hline $\begin{array}{c}\text { Persenta } \\
\text { Se Rata- }\end{array}$ & & \\
\hline Katagori & Cukup & \\
\hline
\end{tabular}

Berdasarkan hasil pengamatan di atas dapat kita simpulkaan bahwa tahap awal atau siklus I kemampuan guru dalam menyusun melaksanakan tanggung jawab serta program kerja masih sangat jauh dari harapan. Bahkan setelah dilakukan beberapa kali uji dalam menyusun program kerja hanya $38 \%$ guru yang menguasai cara menyussun dengan efekttif. Pada dasarnya siklus II memiliki prosedur yang sama dengan siklus I, hanya saja perlu dilakukan tindakan-tindakan serta perbaikan pada poin-poin yang dilihat ada kelemahan serta mempertimbangkan hal-hal yang sudah berjalan dengan baik. Tidak menutup kemungkinan juga dilakukan modifikasi terhadap hal-hal sudah baik supaya tindakan yang diberikan tidak merasa jenuh.

\begin{tabular}{|c|l|c|}
\hline No & \multicolumn{1}{|c|}{ Nama } & Skor Penilaaian \\
\hline 1 & Nurjanida, S. Pd. I & 3 \\
\hline 2 & Megawati, S. Pd. I & 3 \\
\hline
\end{tabular}


Jurnal Sosial Humaniora Sigli (JSH)

p ISSN : 2615-3688

$e$ ISSN : 2716-0270

http://journal.unigha.ac.id/index.php/JSH

\begin{tabular}{|c|l|c|}
\hline 3 & Mukhsin, S. Pd. I & 3 \\
\hline 4 & Razali, S. Pd. I & 3 \\
\hline 5 & Murniati, S. Pd. I & 3 \\
\hline 6 & Mawarni, S. Pd. I & 3 \\
\hline 7 & Nurlaili, S. Pd. I & 3 \\
\hline 8 & Azimar, S. Pd. I & 3 \\
\hline 9 & Masriani, S. Pd. I & 3 \\
\hline 10 & Darni, S. Ag & 3 \\
\hline Persentase Rata-rata & Cukup \\
\hline \multicolumn{2}{|l}{ Katagori } \\
\hline
\end{tabular}

Berdasarkan hasil uji kompetensi di atas dapat kita simpulkan bahwa guru yang menjadi peserta telah menunjukan perkembangan kemampuan dari pada sebelumnya pada siklus I dan yang telah memperoleh bimbingan teknis sesuai dengan arahan dari pengawas. Hasil uji kemampuan dalam menyusun program kerja pada siklus II sebanyak 10 orang guru sudah sesuai dengan mendapatkan nilai yang amat baik sehingga bimbingan teknis dan bisa dikatakan sebagai sebuah perkembangan kemampuan guru yang signifikan.

Tabel hasil tes kemampuaan pada Siklus II

\begin{tabular}{|c|c|l|r|l|}
\hline No & $\begin{array}{r}\text { Skala } \\
\text { Nilai }\end{array}$ & $\begin{array}{l}\text { Jumlah } \\
\text { Guru }\end{array}$ & Persentase & Keterangan \\
\hline 1 & $85-100$ & 6 & $60 \%$ & Amat Baik \\
\hline 2 & $75-86$ & 3 & $30 \%$ & Baik \\
\hline 3 & $65-76$ & 1 & $10 \%$ & Cukup \\
\hline 4 & $55-64$ & - & - & Kurang \\
\hline 5 & $\leq 54$ & - & - & Sangat Kurang \\
\hline
\end{tabular}

Setelah dilakukan cross-check melalui wawancara dengan kepala sekolah, dapat disimpulkan bahwa kepala sekolah melakukan pembinaan pada seminar atau workshop dengan memberikan informasi dan mengikutsertakan para guru dalam kegiatan seminar. Diperoleh informasi bahwa sebagian besar guru di Madrasah Ibtidaiyah Negeri 2 Pidie sudah dapat mengoperasikan komputer dan notebook dengan cukup baik, didukung dengan adanya

sarana internet memudahkan para guru untuk dapat mengakses materi belajar yang akan diajarkan kepada siswa.

Berdasarkan analisis hasil penelitian pembinaan profesionalitas guru oleh kepala sekolah pada kegiatan kelompok kerja guru menunjukkan bahwa yang termasuk dalam kategori sangat baik adalah mengembangkan soal-soal penilaian dan menyelesaikan permasalahan yang dihadapi guru berkenaan dengan proses belajar mengajar. Sementara itu, pembinaan profesionalitas guru oleh kepala sekolah pada kegiatan kelompok kerja guru yang termasuk dalam kategori baik, yaitu mengembangkan lembar kerja, alat bantu pelajaran dan mengembangkan kemampuan profesional guru dalam mengajar. Hasil analisis skor rata-rata pembinaan profesionalitas guru pada kelompok kerja guru menunjukkan bahwa termasuk dalam kategori sangat baik.

Berdasarkan analisis hasil penelitian pembinaan profesionalitas guru oleh kepala sekolah pada kegiatan supervisi menunjukkan bahwa yang termasuk dalam kategori sangat baik yaitu pada, membimbing guru dalam mengembangkan dan menggunakan media pendidikan dan fasilitas pembelajaran di madrasah memotivasi guru untuk memanfaatkan teknologi informasi dalam pembelajaran tiap mata pelajaran di madrasah dan membimbing guru dalam melaksanakan kegiatan pembelajaran di kelas/di lapangan untuk mengembangkan potensi siswa.

Sementara itu, pembinaan profesionalitas guru oleh kepala sekolah pada kegiatan supervisi yang termasuk dalam kategori baik, yaitu membimbing guru dalam memilih dan menggunakan strategi / metode / teknik pembelajaran dengan melihat RPP. Berdasarkan analisis hasil penelitian pembinaan profesionalitas guru oleh kepala sekolah pada kegiatan pendidikan dan pelatihan menunjukkan bahwa yang termasuk dalam kategori sangat baik yaitu, mengikutsertakan guru dalam diklat tentang penyusunan soal-soal (Ulangan 
Jurnal Sosial Humaniora Sigli (JSH)

p ISSN : 2615-3688

e ISSN : 2716-0270

http://journal.unigha.ac.id/index.php/JSH

Harian, UKK, dan lainnya) mengikutsertakan guru dalam diklat tentang pelaksanaan PAIKEM GEMBROT mengikutsertakan guru dalam diklat dalam pengembangan metodologi pembelajaran misalnya untuk (IPA, Matematika, dan lainnya) dan mengikutsertakan guru dalam diklat tentang penyusunan bahan ajar.

\section{KESIMPULAN}

Berdasarkan pada hasil penelitian dan pembahasan mengenai "Pembinaan Profesionalitas Guru Oleh Kepala Sekolah di Madrasah Ibtidaiyah Negeri 2 Pidie dapat diambil kesimpulan bahwa pembinaan profesionalitas guru oleh kepala sekolah di Madrasah Ibtidaiyah Negeri 2 Pidie termasuk dalam kategori baik dengan persentase sebesar $(85,61 \%)$. Hal ini dikarenakan kepala sekolah rutin dalam melaksanakan pembinaan guru khususnya pembinaan melalui supervisi, serta memfasilitasi guru untuk berpartisipasi aktif dalam KKG, seminar atau workshop, dan pendidikan dan pelatihan. Pembinaan profesionalitas guru oleh kepala sekolah secara keseluruhan sudah baik, hendaknya kepala sekolah dapat mempertahankan dan meningkatkan pembinaannya terhadap guru dengan tetap melakukan pembinaan secara rutin, selain pembinaan yang tetap dilakukan secara rutin, kepala sekolah juga menambah kegiatan pembinaan kepada guru misalnya melalui kegiatan karyawisata, dan lainlain. Kepala sekolah juga diharapkan untuk mengikuti seminar atau diklat dalam hal peningkatan keprofesionalan kepala sekolah serta berusaha menjadi teladan bagi para guru di sekolah.

\section{DAFTAR PUSTAKA}

Aan Komariah dan Cepi Triatna. (2006). Visionary Leadership, Menuju Sekolah Efektif.Jakarta: Bumi Aksara.
Abdul Rohim. (2011). Pembinaan Kompetensi Profesional Guru di SMP Assalam

Cipondoh Tangerang.Skripsi. Tangerang: FIP UIN.

Akhmad Afroni. (2013). Kompetensi Kepala Sekolah Sebagai Supervisor

Pembelajaran Dalam Upaya Peningkatan Kompetensi Guru.Jurnal. Jakarta: FIP UIN.

Ali Imron. (1995). Pembinaan Guru Indonesia. Jakarta: PT Dunia Pustaka Raya. Danim dan Suparno. (2009). Manajemen dan Kepemimpinan Transformasional Ke kepala sekolahan. Jakarta: Rineka Cipta.

Departemen Pendidikan dan Kebudayaan. (1990). Kamus Besar Bahasa Indonesia. Jakarta: Balai Pustaka.

Depdikbud. (1994). Pedoman Pelaksanaan Sistem Pembinaan Profesional Guru Sekolah Dasar Melalui Gugus Sekolah. Jakarta:

Depdiknas. (1996c). Pedoman Profesional Guru Sekolah Dasar. Jakarta: Depdikbud. Depdiknas. (2004). Standar Kompetensi Guru Sekolah Dasar. Jakarta: Dirjen Dikdasmen.

Dwi Siswoyo,dkk. (2008). Ilmu Pendidikan. Yogyakarta: UNY Press.

Mulyasa. (2007). Standar Kompetensi dan Sertifikasi Guru. Bandung: PT Remaja Rosdakarya

Fachruddin Saudagar. (2009). Pengembangan Profesionalisme Guru. Jakarta: Gaung Persada. 
Jurnal Sosial Humaniora Sigli (JSH)

p ISSN : 2615-3688

e ISSN : 2716-0270

http://journal.unigha.ac.id/index.php/JSH

\begin{tabular}{lccr}
\hline Fasli & Jalal. & (2008). & Reformasi \\
& Pendidikan \\
Otonomi & Dalam & Konteks
\end{tabular}

Daerah.Yogyakarta: Adi Cipta Karya Nusa.

Hamzah B. Uno. (2008). Profesi Kependidikan, Problema, Solusi, dan Reformasi Pendidikan di Indonesia. Jakarta: Bumi Aksara.

Hartati Sukirman dkk. (2008). Administrasi dan Supervisi Pendidikan. Yogyakarta: UNY Press.

Ibrahim Bafadal. (2006). Peningkatan Profesionalisme Guru Sekolah Dasar. Jakarta: Bumi Aksara.

KBBI. (2005). Kamus Besar Bahasa Indonesia. Jakarta: Balai Pustaka. Kunandar. (2007). Guru Profesional. Jakarta Utara: PT Rajagrafindo Persada. Moh.Uzer Usman. (2006). Menjadi Guru Profesional. Bandung: PT Remaja Rosdakarya. N.A. Ametembun. (2000). Kepengawasan dalam Penyelenggaraan Pendidikan Suatu Refleksi Bagi Para Penilik, Pengawas, Kepala-Kepala Sekolah dan Guru-Guru. Bandung: Suri.

M.Chan.M dan Tuti T.Sam. (2005). Kebijakan Pendidikan Era Otonomi Daerah. Jakarta: Raja Grafindo Persada.

Peraturan Menteri Pendidikan Nasional RI Nomor 13 Tahun 2007 tentang Kepala Sekolah.

Ondi Saondi dan Aris Suherman. (2010). Etika Profesi Keguruan. Bandung:

Rafika Aditama. Peraturan Pemerintah No. 19 Tahun 2005 Tentang Standar Nasional Pendidikan.
Permendiknas No. 16 Tahun 2007 Tentang Standar Kualifikasi Akademik dan Kompetensi Guru. Peraturan Pemerintah No. 74 Tahun 2008 Tentang Guru.

Riduwan dan Akdon. (2007). Rumus dan Data dalam Analisis Statistika. Bandung: Alfabeta.

Sahertian. (2000). Konsep Dasar Supervisi Pendidikan Dalam Rangka Pengembangan Sumber Daya Alam. Jakarta: Rineka Cipta.

Saifuddin Azwar. (2006). Reliabilitas dan Validitas. Yogyakarta: Pustaka Pelajar Offset.Group.

Sudarwan Danim. (2011). Pengembangan Profesi Guru. Jakarta: Prenada Media

Sugiyono. (2009). Metode Penelitian Kuantitatif Kualitatif dan R\&D. Bandung: Alfabeta.

Sugiyono. (2010). Metode Penelitian Pendidikan, Pendekatan Kuantitatif, Kualitatif, dan R\&D. Bandung: Alfabeta.

Suharsimi Arikunto. (2001). Dasar-Dasar Evaluasi Pendidikan. Jakarta: Bina Aksara.

Suharsimi Arikunto dan Lia Y. (2008). Manajemen Pendidikan. Yogyakarta: Aditya Media.

Suparlan. (2005). Menjadi Guru Efektif. Yogyakarta: Hikayat. Suryosubroto. (2004). Manajemen Training. Yogyakarta: FIP UNY.

Sutjipto dan Raflis Kosasi. (1999). Profesi Keguruan. Jakarta: Rineka Cipta. 
Jurnal Sosial Humaniora Sigli (JSH)

p ISSN : 2615-3688

$e$ ISSN : 2716-0270

http://journal.unigha.ac.id/index.php/JSH

Syaiful Sagala. (2009). Kemampuan Profesional dan Tenaga Kependidikan. Bandung: Alfabeta.

Tulus Winarsunu. (2002). Statistik dalam Penelitian Psikologi dan Pendidikan.Malang: UMM Press.

Undang-Undang No. 14 Tahun 2005 Tentang Guru dan Dosen. Undang-Undang
No. 20 Tahun 2003 Tentang Sistem Pendidikan Nasional.

Wahjosumidjo. (2003). Kepemimpinan Kepala Sekolah. Jakarta: PT Raja Grafindo Persada.

Wina Sanjaya. (2009). Strategi Pembelajaran Berorientasi Standar Proses Pendidikan. Jakarta: Kencana Prenada Media Group. 